\title{
Effect of Corophium volutator on the abundance of benthic diatoms, bacteria and sediment stability in two estuaries in southeastern England
}

\author{
Veronika Gerdol, R. G. Hughes* \\ School of Biological Sciences, Queen Mary and Westfield College, University of London, London E1 4NS, United Kingdom
}

\begin{abstract}
In in situ experiments the abundance of Corophium volutator (Pallas) in areas of intertidal mudflats of the Rivers Crouch and Blackwater, southeastern England, was reduced by spraying with an insecticide. In these sprayed areas the densities of bacteria and diatoms increased significantly, as did the concentrations of chlorophyll $a$. These changes were attributed to the reduction in the grazing pressure by $C$. volutator, which is a deposit feeder that consumes diatoms and bacteria. The shear strength of the sediment in the sprayed areas increased, probably for 2 reasons: firstly because of increased amounts of mucopolysaccharide secreted by the microflora, and secondly because of the decreased water content of the sediment. The activities of C. volutator may, therefore, exacerbate the erosion that is prevalent in estuaries in southeastern England.
\end{abstract}

KEY WORDS: Corophium volutator - Estuarine sediment - Erosion - Benthic bacteria - Epipelic diatoms

\section{INTRODUCTION}

Almost all of the 6000 ha of saltmarshes and their adjacent mudflats in southeastern England are Sites of Special Scientific Interest or National Nature Reserves (Burd 1992), mostly because they are of international importance for migrant and overwintering birds. Southeastern England is sinking relative to sea level, as a result of isostatic adjustment following the last glaciation, and any sea level rise due to global warming. Deposition of sediment at a rate equal to the apparent rise in sea level is necessary for the mudflats and marshes to maintain their vertical position. How ever, the marshes are deteriorating rapidly, particularly because of erosion at their seaward edge but also because of internal disintegration. The reasons for this erosion in these once sedimentary environments are not understood (Burd 1992) and a greater understand ing of the processes which affect the balance between erosion and deposition in these precious habitats is important.

- Addressee for correspondence
The microflora and fauna of estuarine sediments can stabilize those sediments because they secrete mucopolysaccharides which bind sediment grains together Bacteria, fungi and protozoa secrete mucopolysaccharides (Hobbie \& Lee 1980, Grant et al. 1986, Decho 1990 ) but the most important organisms in this respect are the epipelic diatoms, which secrete mucopolysaccharides to enable them to move during their short distance migrations to and from the surface (Holland et al. 1974, Harper 1977, Paterson 1986, Underwood \& Paterson 1993a, b). Macrofauna too may increase sediment stability by binding particles with the secretions used to construct their tubes (Yingst \& Rhoads 1978). Meadows \& Tait (1989) demonstrated that Corophium volutator (Pallas) could increase the shear strength of sediment by the particle-binding secretions of the burrow wall, by compaction and by reducing the water content of the sediment.

Corophium volutator is abundant locally on the mudflats at the seaward edge of saltmarshes, and in the creeks that dissect the saltmarshes, where densities may exceed $140000 \mathrm{~m}^{-2}$ (Gerdol 1994). Gerdol \& Hughes (1994, this issue) concluded that in these estuaries $C$. volutator feed on surface sediments and 
consume benthic diatoms, bacteria and organic matter. Consequently $C$. volutator has the potential to reduce sediment stability by reducing the degree to which sediment grains are bound together by microflora secretions. The aim of this study was to examine the effect of $C$, volutator on chlorophyll a (chl a) concentrations, which are a measure of total algal abundance, on the abundance of diatoms and bacteria, and on sediment stability, which was assessed by measuring the shear strength.

\section{METHODS}

To assess the effects of Corophium volutator on the abundance of sediment microorganisms and sediment stability, the amphipods were removed from small areas of the mudflat by spraying the sediment with a pyrethrum-based insecticide (Bug Gun, ICI). In similar experiments Underwood \& Paterson (1993a, b) used formaldehyde, which killed all the organisms initially. In this study the more selective biocide was preferred and avoided the need to sieve the sediment which would disrupt its structure and the stratification of the biota in it. Four different experiments were conducted at 2 sites where $C$. volutator was abundant and the only common macrofauna species (Fig. 1). At Wallasea Island (River Crouch) Expt W1 terminated on Day 73 (5 July 1991) and Expt W2 on Day 36 (17 March 1993). At Maldon (River Blackwater) Expt M1 terminated on Day 58 (5 December 1991) and Expt M2 on Day 67
(21 May 1992). In each experiment 2 patches of sediment of varied size $(30 \times 30 \mathrm{~cm}$ to $50 \times 100 \mathrm{~cm})$ were sprayed approximately every $10 \mathrm{~d}$. At the end of each experiment samples of sediment were collected from the sprayed areas, and from adjacent unsprayed areas, for estimation of the densities of the macrofauna, diatoms and bacteria and for chl a analysis. Measurements of sediment shear strength were made in situ.

The macrofauna abundance in all the experiments was determined by taking 5 cores of mud $110 \mathrm{~cm}$ deep. $3.9 \mathrm{~cm}$ in diameter) from sprayed sediment and 5 from unsprayed sediment. The cores were sieved individually through a sieve of mesh size $0.354 \mu \mathrm{m}$ and the organisms identified and counted.

Chl a concentrations of the sediment were measured using spectrophotometry (e.g. Sundbäck \& Jonsson 1988, Underwood \& Paterson 1993a), In Expt W1, 15 cores of sediment (1 cm depth, $1.5 \mathrm{~cm}$ diameter) were collected from sprayed areas and 15 from unsprayed areas. In the other 3 experiments 10 cores $(1.5 \mathrm{~cm}$ deep, $0.8 \mathrm{~cm}$ diameter) from each treatment were collected. The samples were taken to the laboratory in the dark and frozen. The frozen sediment was crushed in a glass petri-dish and freeze-dried overnight in an Edwards Modulyo freeze-drier. Each dry sediment sample was placed in a centrifuge tube previously washed with $90 \%$ acetone, shaken in $10 \mathrm{ml} 90 \%$ acetone, covered with parafilm to avoid evaporation and left overnight in the dark at $3^{\circ} \mathrm{C}$. The following day the centrifuge tubes were shaken and centrifuged for $5 \mathrm{~min}$ at $3000 \times \mathrm{g}$. The absorbance of the supernatant

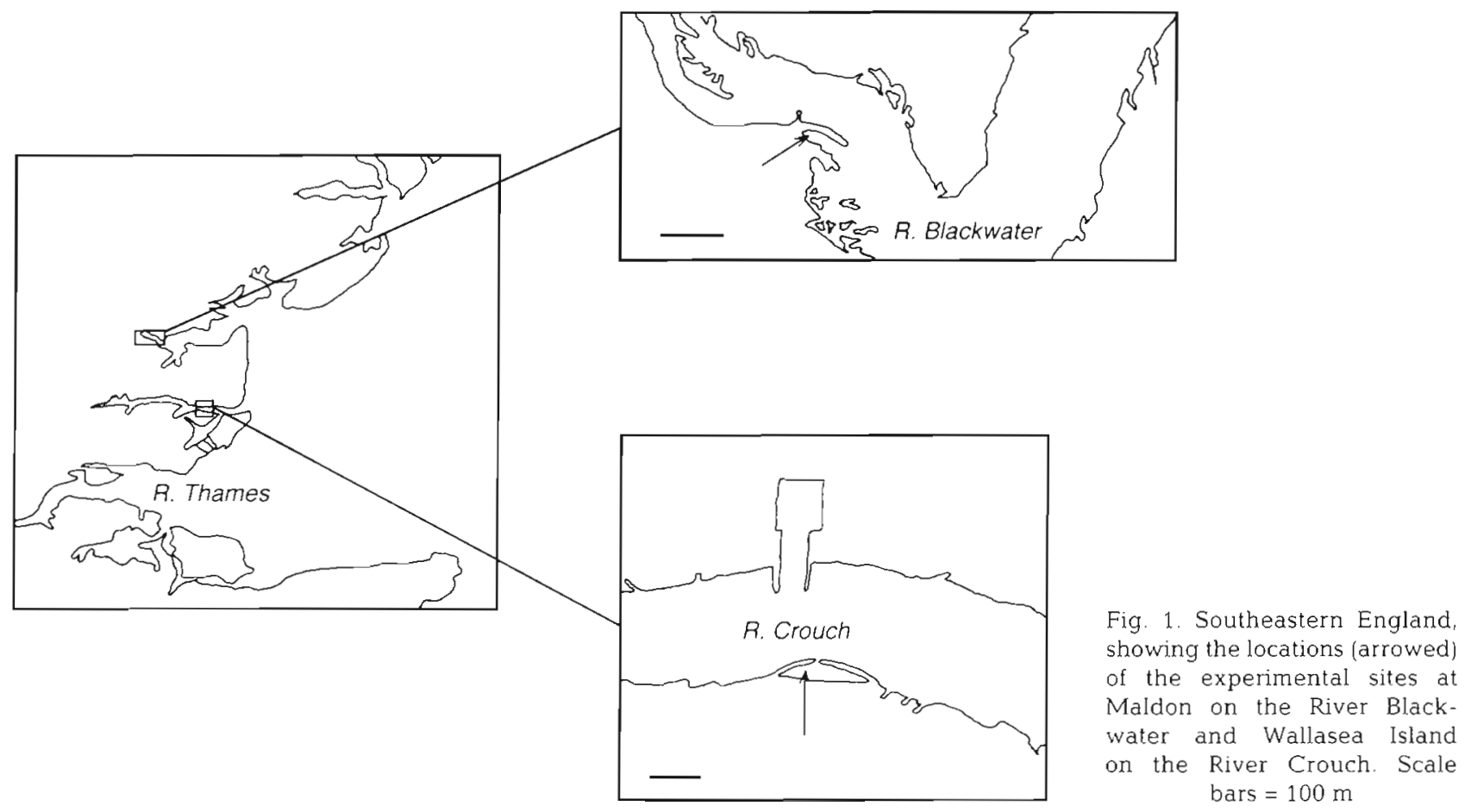


at $750,664,647$ and $630 \mathrm{~nm}$ was read and the chl a concentrations calculated according to the equation given in Parsons et al. (1985).

Although chl a concentrations may be almost totally attributable to diatoms (Underwood \& Paterson 1993b) the abundance of benthic diatoms was determined directly in 2 experiments (W2 and M2). The method used was based on that described by Sundbäck \& Jonsson (1988). Ten cores of sediment $(1.5 \mathrm{~cm}$ deep, $0.8 \mathrm{~cm}$ diameter) were collected from sprayed sediment and 10 from unsprayed sediment and immediately placed in $10 \mathrm{ml}$ of a $2 \%$ solution of formaldehyde in artificial sea water (Tropic Marin Neu, TMN). After thorough mixing $1 \mathrm{ml}$ of each sample was extracted, diluted in $10 \mathrm{ml}$ of TMN and sonicated for $2 \mathrm{~min}$ (L\&R Ultrasonic, Model T9). The diatoms were counted in a haemocytometer (Neubauer, depth $0.1 \mathrm{~mm}$ ) using a fluorescence microscope at $315 \times$ magnification. Only live diatoms were counted and these were recognized by their chloroplasts which fluoresce red in UV light. In each sample the diatoms in 10 randomly chosen fields of view were counted and diatom abundance calculated as number $\mathrm{cm}^{-2}$ of sediment surface.

For estimation of bacteria abundance 10 cores of sediment $(1.5 \mathrm{~cm}$ deep, $0.8 \mathrm{~cm}$ diameter $)$ were collected from sprayed and unsprayed sediment in Expts $\mathrm{W} 1, \mathrm{~W} 2$ and $\mathrm{M} 2$ and placed in $10 \mathrm{ml}$ of $2 \%$ formaldehyde solution in filtered $(0.2 \mu \mathrm{m})$ and autoclaved TMN. In the laboratory each sample was shaken, mixed using a whirlimixer for $15 \mathrm{~s}$ and sonicated for $1 \mathrm{~min}$ to separate the bacteria from the sediment particles. The samples were left to settle for $5 \mathrm{~min}$ and $0.1 \mathrm{ml}$ of the supernatant diluted in $10 \mathrm{ml}$ of filtered and autoclaved TMN. Two ml of these samples was filtered on a $0.2 \mu \mathrm{m}$ polycarbonate filter, stained with $0.5 \mu \mathrm{g} \mathrm{ml}-1$ 4,6diamidino-2-phenylindole (DAPI), and mounted on slides using Citifluor. The slides were kept in a dark refrigerator until used. The bacteria were counted using a fluorescence microscope at $315 \times$ magnification. DAPI is a specific DNA stain and the DAPI-DNA complex fluoresce bright blue when excited with light at a wavelength of $365 \mathrm{~nm}$. The unbound DAPI and DAPI bound to non-DNA material fluoresce a weak yellow. The bacteria were easily distinguishable from other organisms and organic particulate matter. The number of randomly selected fields of view necessary to see at least 400 bacteria on each slide were used to calculate bacteria abundance.

In Expts M1, M2 and W2 the dry weight of 10 samples of $1 \mathrm{ml}$ of sediment from each of the sprayed and unsprayed areas was found by drying the samples to constant weight in an oven at $60^{\circ} \mathrm{C}$.

Shear strength is related to the critical erosion velocity, the velocity at which the sediment begins to erode (Otsubo \& Muraoka 1988), and following Meadows \&
Tait (1989) the shear strength of the sediment was estimated by measuring the penetration of the sediment by a cone penetrometer. In each of the 4 experiments 10 cores of sediment $(3.4 \mathrm{~cm}$ diameter, $5 \mathrm{~cm}$ deep) were collected from the sprayed areas and 10 from unsprayed areas within $1 \mathrm{~h}$ of the time of low tide and immediately the depth of penetration by the cone was measured. The depth of penetration by the cone is inversely proportional to the shear strength, which was calculated by the method described by Hansbo (1957) and Meadows \& Tait (1989).

\section{RESULTS}

On all occasions the only species of macrofauna abundant in the unsprayed sediment was Corophium volutator, and only occasionally were other species recorded. In all 4 experiments there were significantly fewer C. volutator in the sprayed areas than in the adjacent unsprayed areas ( $p<0.05$, unpaired $t$-test) (Fig. 2).

In all 4 experiments the chl a concentrations of the sprayed sediment were approximately half and significantly lower $(\mathrm{p}<0.05$, unpaired $t$-test $)$ than those of the unsprayed sediment (Fig. 3).
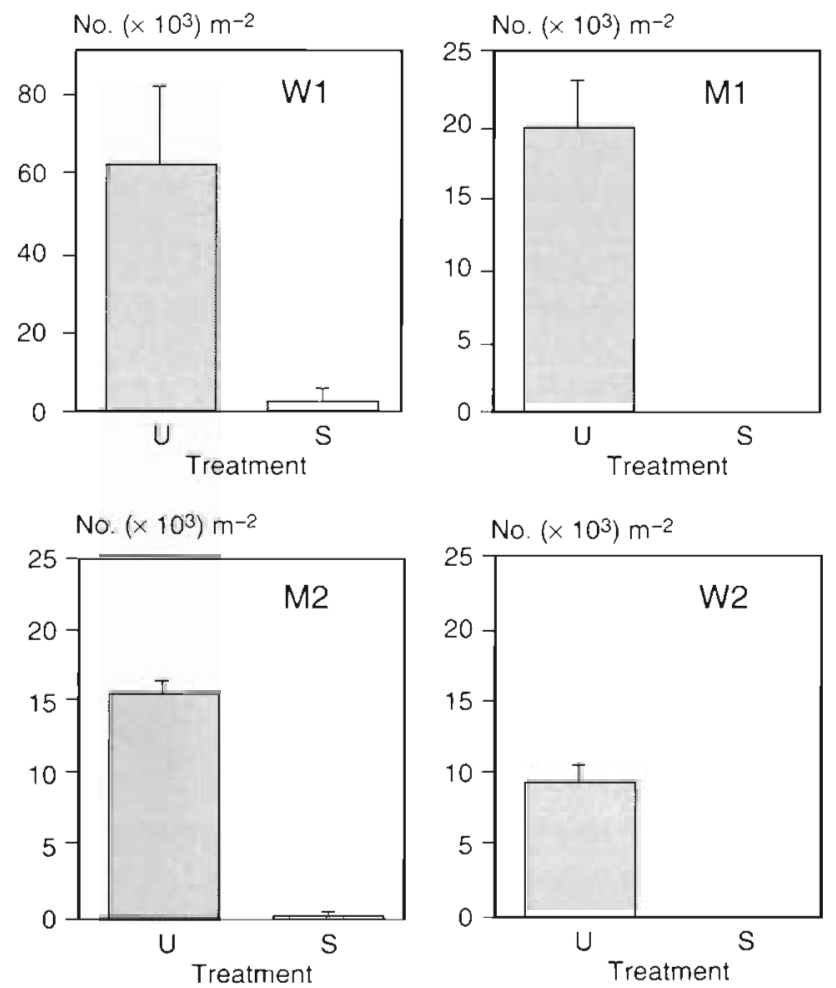

Fig. 2. Corophium volutator. Mean (+SE) abundance of amphipods in unsprayed (U) and sprayed (S) sediment in the 4 experiments. The t-values for $\mathrm{W} 1$ and $\mathrm{M} 2$ are 9.49 and 20.47 respectively. No $C$. volutator were found in the sprayed sediments in Expts M1 and W2 

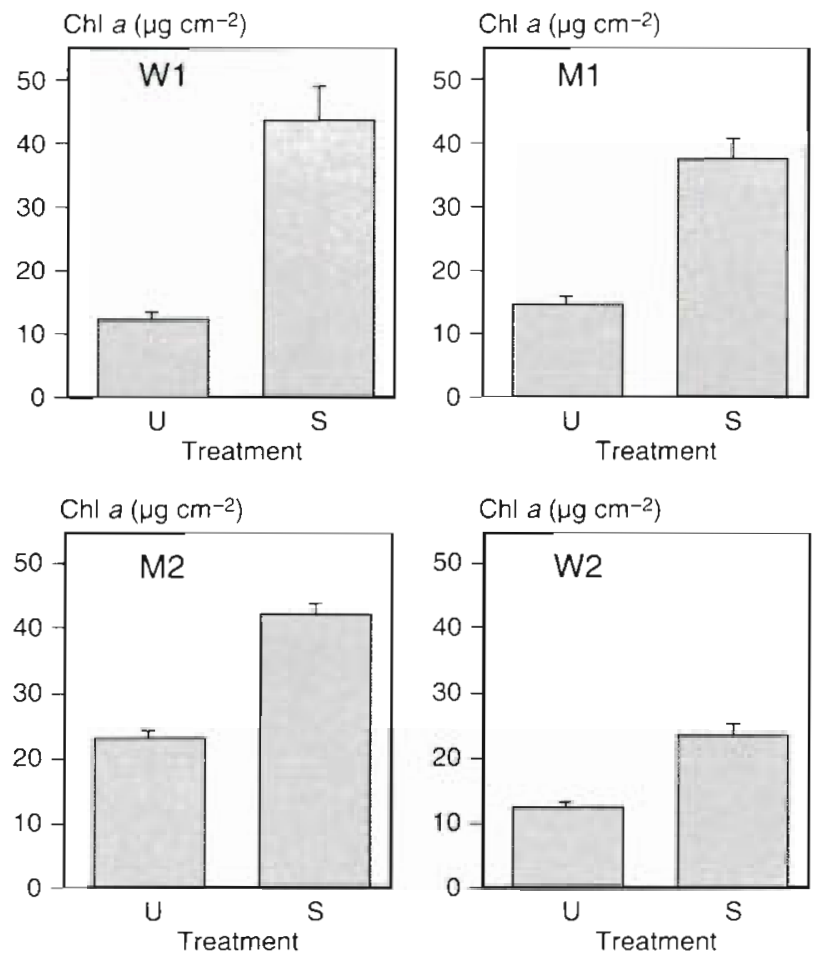

Fig. 3. Mean (+ SE) chl a concentration in unsprayed (U) and sprayed (S) sediment in Expts W1, M1, M2 and W2. The $t$-values are $5.49,7.58,10.34$ and 6.65 respectively

Benthic diatoms were significantly more abundant in the sprayed sediments than in the unsprayed sediments in both experiments where their abundance was estimated (Fig. 4) ( $p<0.05$, unpaired $t$-test). This difference was apparent as a darker (brown) colouration and a raised surface of the sprayed sediment (Fig. 5).

The densities of bacteria in the sprayed sediments were significantly higher $(p<0.05$, unpaired $t$ test) than in the unsprayed sediments in Expts $M 2$ and $\mathrm{W} 2$ but no significant difference between the 2 treatments was found in Expt M1 (Fig. 6).

The mean dry weight of $1 \mathrm{ml}$ of sprayed sediment was higher than that of the unsprayed control sediment. In Expts M1 and M2 this difference was significant $(p<0.05$, unpaired t-test) but not in Expt W2 (Fig. 7). These data indicate that the sprayed sediment had a lower porosity than the unsprayed natural sediment, which would have a higher water content. Indeed at low tide the surface of the natural (unsprayed) sediment remained wet
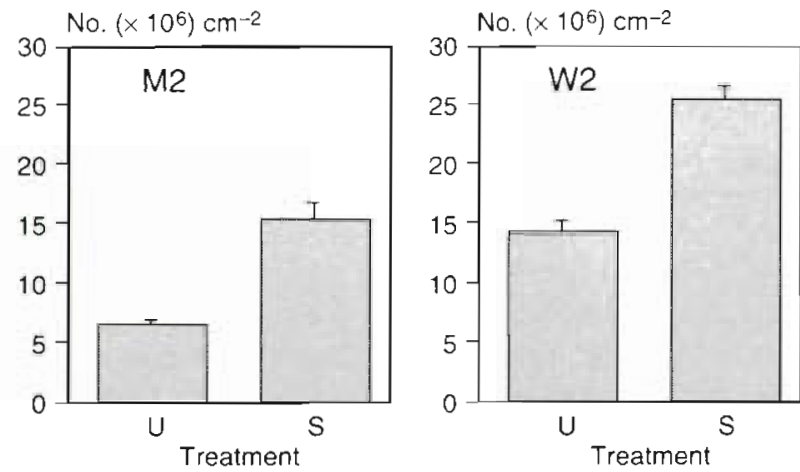

Fig. 4. Mean ( $+\mathrm{SE}$ ) abundance of diatoms in unsprayed (U) and sprayed (S) sediment in Expts $\mathrm{M} 2$ and $\mathrm{W} 2$. The $t$-values are 6.24 and 7.98 respectively

but the sprayed sediment, which was slightly raised, was noticeably drier (Fig. 5).

The shear strength of the sprayed sediment was significantly higher than that of unsprayed sediment in Expts M1, W1 and M2 ( $p<0.05$, unpaired $t$-test) but the difference between the two was not significant in the relatively short Expt W2 (Fig, 8), when the lowest density of Corophium volutator in unsprayed sediment was recorded.

\section{DISCUSSION}

Gerdol \& Hughes (1994) demonstrated that at Wallasea Island Corophium volutator are primarily deposit feeders that consume large numbers of diatoms,

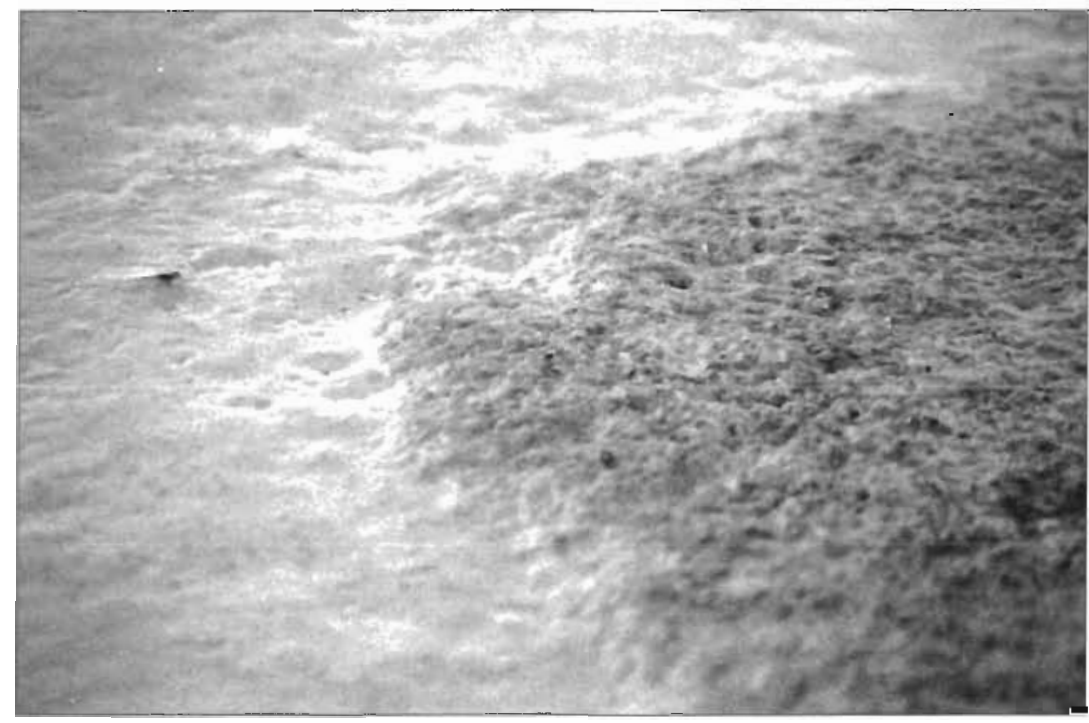

Fig. 5. An area of mudflat $12 \mathrm{~cm}$ wide at Maldon (May 1992) showing the edge of a sprayed patch of sediment. The sprayed sediment to the right is darker, because of the enriched diatom flora, and slightly raised above the wetter, lighter unsprayed sediment to the left 

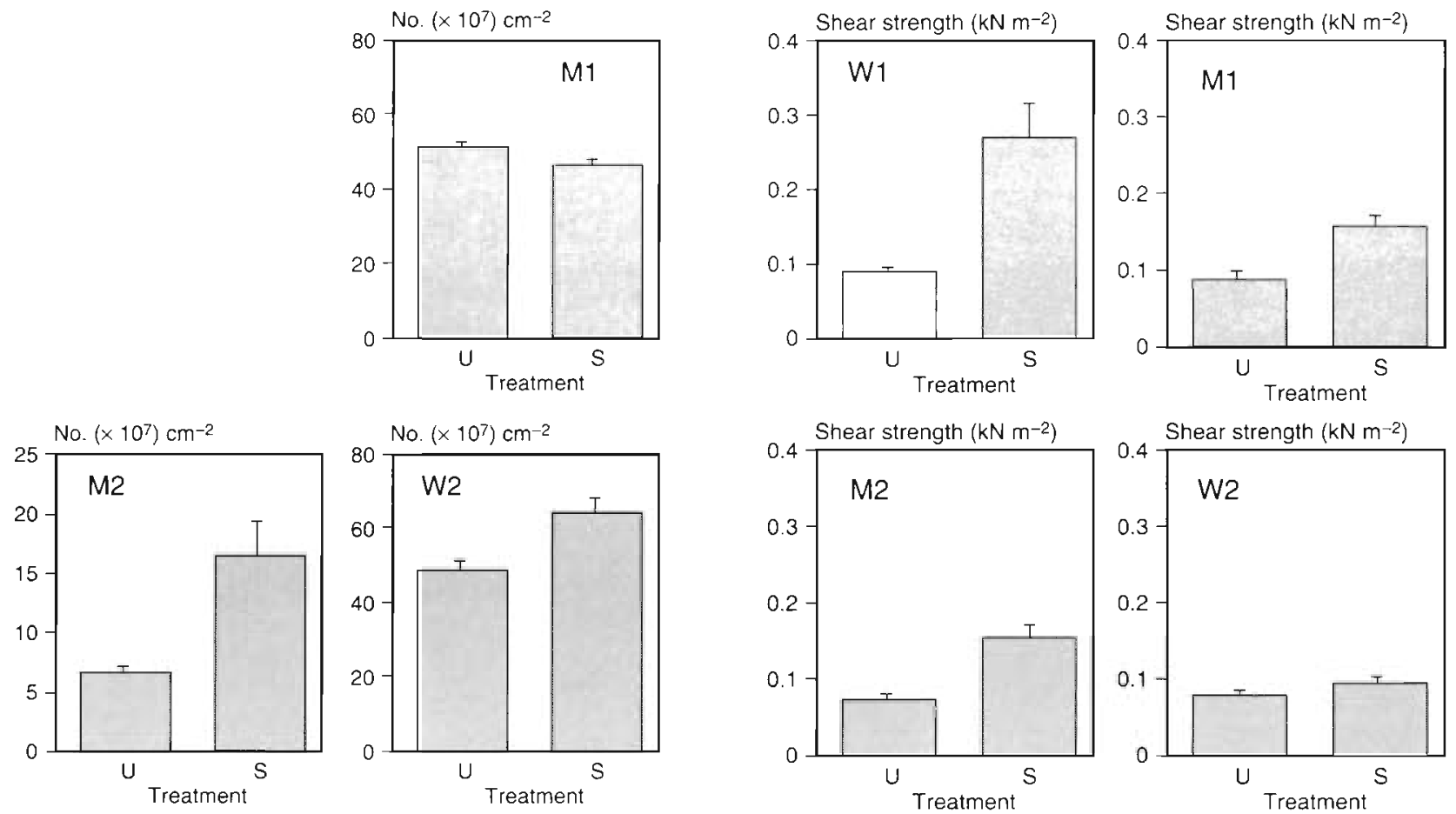

Fig. 6. Mean (+ SE) abundance of bacteria $\mathrm{cm}^{-2}$ in unsprayed (U) and sprayed (S) sediment in Expts M1, M2 and W2. The $t$-values are $1.75,3.36$ and 3.64 respectively

Fig. 8. Mean shear strength (+ SE) of unsprayed $(U)$ and sprayed (S) sediment in Expts W1, M1, M2 and W2. The $t$-values are $3.65,4.75,4.11$ and 2.04 respectively

together with organic material and sediment particles. Bacteria attached to these particles may also form an important part of their diet (Fenchel et al. 1975 , Murdoch et al. 1986), as may the adherent secretions of the microflora.

Several authors have reported a negative correlation between the presence of Corophium volutator and densities of bacteria, diatoms, algae and chl a concentrations. Although the reasons for such correlations were presumed to be due to grazing (Mossman 1977, Coles 1979, Hargrave et al. 1983, Hawkins 1985) or disturbance (Mossman 1977, Murdoch et al. 1986), there was no evidence of a causal relationship, and the negative correlations could have been the coincidental product of opposite responses to spatially or temporally variable environmental parameters. This study provides direct evidence that the reduction in density, or the removal, of C. volutator facilitates increases in the concentrations of chl $a$, and in the abundance of diatoms and bacteria (on 2 of 3 occasions). These changes cannot be attributable to the meiofauna, since studies in progress reveal that while the insecticide also removed the benthic copepods, the more numerous nematodes actually increased in abundance in sprayed areas. The only conclusion is that in undisturbed sediment $C$. volutator reduce the abundance of diatoms and bacteria, mostly by their feeding activities. C. volutator may also decrease 
bacteria densities indirectly in 2 ways. Firstly, the surface area available for colonisation in the bioturbated sediment is decreased, and secondly, the reduction in diatom densities may reduce the amounts of mucopolysaccharides which are bacterial substrates. Cammen \& Walker (1986) reported a strong correlation between microalgae biomass and bacteria biomass. They suggested that bacteria abundance was determined by the surface area available for colonisation and by the presence of microalgal secretions.

Bioturbation by infauna generally reduces compaction and increases the water content of sediment (Rhoads \& Young 1970, Rhoads 1974). On 2 of 3 occasions in this study the dry weight of the same volume of sediment was significantly higher in the sprayed areas than in the unsprayed areas. This indicates that the presence of Corophium volutator increased pore space, and saturation on emersion, by retention of water by the secretions that line their burrows (Meadows \& Tait 1989)

There are 2 explanations for the significant increases in the shear strength of the sprayed sediment in Expts W1, M1 and M2. Firstly, the presence of Corophium volutator increases the sediment's water content and there is an inverse relationship between water content and shear strength (Hansbo 1957). Secondly, C. volutator decreases the abundance of diatoms and bacteria which would otherwise increase shear strength by their secretions. Underwood \& Paterson $(1993 \mathrm{a}, \mathrm{b})$ sprayed patches of sediment with formaldehyde to kill the microflora and other biota, and the lower amounts of carbohydrate in the sediment facilitated the removal of sediment by water movements. C. volutator have a similar effect to such spraying; accretion of sediment on insecticide-sprayed patches was apparent even after only $2 \mathrm{wk}$ (Fig. 5). The conclusion that $C$. volutator decreases the shear strength of the sediment contrasts with that of Meadows \& Tait (1989) who found that the amphipods increased the shear strength of recently sieved sediment through lateral compaction by the animals as they burrowed, and by the binding of particles by the mucus of their burrows. The short experiments (3 d) of Meadows \& Tait (1989) would not have detected the long-term effect of decrease in shear strength by $C$. volutator due to the reduction in densities of the microflora, which, this study indicates, outweighs the effects they reported.

Grazing by Corophium volutator on sediment microflora may influence the fate of saltmarshes by exacerbating the sediment erosion that is prevalent at the saltmarsh/mudflat interface, and in the pans and creeks within the marsh vegetation, where the amphipods occur in high densities. This erosion is in sheltered areas where waves and water movement alone cannot be responsible, and Allen \& Pye (1992a) concluded that such erosion could not be attributed to changes in climate or sea level. The possible effects of the infauna on these erosional processes were not considered by these, and other, authors in Allen \& Pye (1992b) nor by Burd (1992). It follows that natural decreases in the abundance of the amphipods should reduce the potential for sediment erosion, and indeed, Daborn et al. (1993) demonstrated how birds might increase sediment stability by consuming $C$. volutator, which allowed an increase in diatom abundance and sediment cohesion. In addition to grazing on microflora C. volutator reduce the potential for colonisation of mudflats by the pioneering saltmarsh plant Salicornia europaea (Gerdol \& Hughes 1993). Therefore the activities of these and other infauna should be taken into account when strategies and tactics for the conservation of these saltmarsh habitats are considered.

\section{LITERATURE CITED}

Allen, J. R. L., Pye, K. (1992a). Coastal saltmarshes: their nature and importance. In: Allen, J. R. L., Pye, K. (eds.) Saltmarshes. Morphodynamics, conservation and engineering significance. Cambridge University Press, Cambridge, p. 1-18

Allen, J. R. L., Pye, K. (1992b). Saltmarshes. Morphodynamics, conservation and engineering significance. Cambridge University Press, Cambridge

Burd, F. (1992). Erosion and vegetation change on the saltmarshes of Essex and north Kent between 1.973 and 1988. (Research and survey in nature conservation, 42.) Nature Conservancy Council, Peterborough

Cammen, L. M., Walker, J. A. (1986). The relationship between bacteria and micro-algae in the sediment of a Bay of Fundy mudflat. Estuar. coast. Shelf Sci. 22: 91-99

Coles, S. M. (1979). Benthic microalgal populations on intertidal sediments and their role as precursors to salt marsh development. In: Jefferies, R. L., Davy, A. J. (eds.) Ecological processes in coastal environments. Blackwell Scientific Publications, Oxford, p. 25-42

Daborn, G. R., Amos, C. L., Brylinsky, M. Christian, H., Drapeau, G., Faas, R. W., Grant, J., Long, B., Paterson, D. M., Perillo, G. M. E., Piccolo, M. C. (1993). An ecological cascade effect: migratory birds affect stability of intertidal sediments. Limnol. Oceanogr. 38: 225-231

Decho, A. W. (1990). Microbial exopolymers secretions in ocean environments: their role(s) in food webs and marine processes. Oceanogr. mar. Biol. A. Rev. 28: 73-153

Fenchel, T., Kofoed, L. H., Lappalainen, A. (1975). Particle size-selection of two deposit feeders: the amphipod Corophium volutator and the prosobranch Hydrobia ulvae. Mar. Biol. 30: 119-128

Gerdol, V. (1994). The distribution and feeding behaviour of the amphipod Corophium volutator (Pallas) and the consequences for the stability of intertidal mudflats. Ph.D. thesis, University of London

Gerdol, V., Hughes, R. G. (1993). Effect of the amphipod Corophium volutator on the colonisation of mud by the halophyte Salicornia europaea. Mar. Ecol. Prog. Ser. 97 61-69

Gerdol, V., Hughes, R. G. (1994). Feeding behaviour and diet of Corophium volutator in an estuary in southeastern England. Mar. Ecol. Prog. Ser 114: 103-108 
Grant, J., Bathman, U. V., Mills, E. L. (1986). The interaction between benthic diatom films and sediment transport. Estuar. coast. Shelf Sci. 23: 225-238

Hansbo, S. (1957). A new approach to the determination of the shear strength of clay by the fall-cone test. Proc. R. Swed. Geotech. Inst. 14: 1-49

Hargrave, B. T., Prouse, N. J., Phillips, G. A., Neame, P. A (1983). Primary production and respiration in pelagic and benthic communities at two intertidal sites in the upper Bay of Fundy. Can. J. Fish. Aquat. Sci. 40 (Suppl. 1): $229-243$

Harper, M. A. (1977). Movements. In: Werner, D. (ed.) The biology of diatoms. (Botanical monographs, 13.) Blackwell Scientific Publications, Oxford, p. 224-249

Hawkins, C. M. (1985). Population carbon budgets and the importance of the amphipod Corophium volutator in the carbon transfer on a Cumberland Basin mudflat, upper Bay of Fundy, Canada. Neth. J. Sea Res. 19: 165-176

Hobbie, J., Lee, C. (1980). Microbial production of extracellular material: importance in benthic ecology. In: Tenore, K. R., Coull, B. C. (eds.) Marine benthic dynamics. University of South Carolina Press, Columbia, p. 341-346

Holland, A. F., Zingmark, R. G., Dean, J. M. (1974). Quantitative evidence concerning the stabilization of sediments by marine benthic diatoms. Mar. Biol. 27: 191-196

Meadows, P. S., Tait, J (1989). Modification of sediment permeability and shear strength by two burrowing invertebrates. Mar. Biol. 101: 75-82

Mossman, D. E. (1977). The energetics of Corophium volutator. Ph.D. thesis, University of London

Murdoch, M. H., Bärlocher, F., Laltoo, M. L. (1986). Population dynamics and nutrition of Corophium volutator (Pallas) in

This article was submitted to the editor the Cumberland Basin (Bay of Fundy). J exp. mar. Biol. Ecol. 103: 235-249

Otsubo, K., Muraoka, K. (1988). Cntical shear stress of cohesive bottom sediments. J. hydraul. Eng. 114: 1241-1256

Parsons, T R., Maita, Y., Lalli, C. M. (1985). A manual of chemical and biological methods for seawater analysis. Pergamon Press, Oxford

Paterson, D. M. (1986). The migratory behaviour of diatom assemblages in a laboratory tidal micro-ecosystem examined by low temperature scanning electron microscopy. Diatom Res. 1: 227-239

Rhoads, D. C. (1974). Organism-sediment relations on the muddy sea floor. Oceanogr. mar. Biol. A. Rev. 12: 263-300

Rhoads, D. C., Young, D. K. (1970). The influence of deposit feeding organisms on sediment stability and community trophic structure. J. mar. Res. 28: 150-178

Sundbäck, K., Jonsson, B. (1988). Microphytobenthic productivity and biomass in sublittoral sediments of a stratified bay, southeastern Kattegat. J. exp. mar. Biol. Ecol. 122: $63-81$

Underwood, G. J. C., Paterson, D. M. (1993a). Recovery of intertidal benthic diatoms after biocide treatment and associated sediment dynamics. J. mar. biol. Ass, U.K. 73: 25-45

Underwood, G. J. C., Paterson, D. M. (1993b). Seasonal changes in diatom biomass, sediment stability and biogenic stabilization in the Severn Estuary. J. mar. biol. Ass. U.K. 73: 871-887

Yingst, J. Y., Rhoads, D. C. (1978). Seafloor stability in Central Long Island Sound: Part II. Biological interactions and their potential importance for seafloor erodibility. In: Wiley, M. L. (ed.) Estuarine interactions. Academic Press, New York, p. 245-260

Manuscript first received: December 15, 1993

Revised version accepted: June 21, 1994 